\title{
PENINGKATAN PARTISIPASI SISWA DALAM PEMBELAJARAN PPKN MELALUI PENERAPAN MODEL TAKE AND GIVE
}

\author{
KOKO \\ SMP Negeri 9 Kota Tasikmalaya \\ Jalan Babakan Siliwangi nomor 9 Tasikmalaya \\ kokomuhammadz777@gmail.com
}

\begin{abstract}
This research generally aims to determine the level of students participation in learning process by using the Cooperative Learning model Take and Give types in increasing students participation in Regional Autonomy material in class IX E SMP Negeri 9 Tasikmalaya in the academic years 2017/2018. This research uses a class action method (action reseach) with data collection techniques through observation, carried out in two cycles. Each cycle consists of planning, action, observation and reflection. Data collected through observation of student activities and educator activities. The result of the first cycle of research, the value of the activity or participation of students in learning by $80.30 \%$, while in the second cycle of $96.97 \%$. Thus there has been an increase in the value of student activities in the learning process by $16.67 \%$. The conclusion of this reseach can be formulated that the application of the cooperative learning model take and give types can increase the participation of students in learning on Regional Autonomy material in class IX E SMP Negeri 9 Tasikmalaya.
\end{abstract}

Keywords: student participation, cooperative learning models type of take and give

\begin{abstract}
Abstrak
Penelitian ini secara umum bertujuan untuk mengetahui tingkat partisipasi siswa dalam proses pembelajaran dengan menggunakan model cooperative Learning tipe take and Give dalam meningkatkan partispasi siswa dalam materi Otonomi Daerah di kelas IX E SMP Negeri 9 Kota Tasikmalaya tahun pelajaran 2017/2018. Penelitian ini menggunakan metode tindakan kelas (action reseach) dengan teknik pengumpulan data melalui observasi, dilaksanakan dalam dua siklus. Setiap siklus terdiri dari kegiatan perencanaan, tindakan, observasi dan refleksi. Data dikumpulkan melalui kegiatan observasi terhadap aktivitas siswa dan aktivitas pendidik. Hasil penelitian siklus kesatu, nilai aktivitas atau partisipasi peserta didik dalam pembelajaran sebesar $80,30 \%$, sedangkan pada siklus kedua sebesar $96,97 \%$. Dengan demikian telah terjadi peningkatan nilai aktivitas peserta didik dalam proses pembelajaran sebesar $16,67 \%$. Kesimpulan penelitian ini dapat dirumuskan bahwa penerapan model cooperative learning tipe take and give dapat meningkatkan partisipasi peserta didik dalam pembelajaran pada materi Otonomi Daerah di kelas IX E SMP Negeri 9 Kota Tasikmalaya.
\end{abstract}

Kata Kunci : partisipasi peserta didik, model cooperative learning tipe take and give 


\section{PENDAHULUAN}

Pembelajaran yang efektif menuntut adanya kerja dan berfungsinya setiap elemen dari sistem pembelajaran yang secara normatif harus ada. Sejalan dengan itu, bekerjanya setiap komponen dari sistem tersebut harus seimbang dan saling menunjang, sinergis. Guru sebagai elemen penting dari sistem pembelajaran melaksanakan tugasnya sejak dia menyusun rencana pembelajaran, melaksanakan pembelajaran, mengevaluasi, menganalisa hasil evaluasi dan melakukan tindak lanjut. Sejalan dengan itu peserta didik dituntut untuk turut berperan serta dalam setiap tahap pembelajaran, sebagai konsekwensi dari pembelajaran demokratis yang sementara ini dipandang sebagai strategi pembelajaran ideal karena dapat dengan efektif mencapai tujuan-tujuan pembelajaran untuk semua ranah. Sarana, media dan metode yang menunjang berkembangnya kreativitas dan kompetensi peserta didik.

Kenyataan menunjukkan bahwa banyak terjadi ketimpangan dari berfungsinya setiap komponen pembelajaran, mungkin karena terlalu dominannya fungsi dari salah satu komponen terutama komponen guru. Siswa sering dipandang sebagai botol kosong yang siap diisi dengan apa saja dan dengan cara bagaimana saja oleh guru, sehingga kehadiran peserta didik di kelas hanya sebagai pendengar setia semata.

Dalam beberapa studi dijumpai fakta bahwa dominasi guru dalam proses pembalajaran masih besar terutama di Indonesia. Misalnya dalam penelitian mengenai perbandingan jumlah kata yang ducapkan guru dan siswa ditemukan kenyataan bahwa dalam waktu 50 menit pembelajaran tercatat rata-rata guru mengucapkan 2.633 kata, sedang peserta didik hanya 197 kata.

Ketidakterlibatan peserta didik dalam proses pembelajaran diakui memang karena beberapa faktor, antara lain: secara sengaja tidak dilibatkan, karena kurangnya motivasi belajar, karena kelelahan dan karena faktor lingkungan. Guru merasa lebih efektif dan efisien jika menggunakan pembelajaran langsung. Dari sisi peserta didik, seperti yang dialami penulis, sedikit sekali peserta didik yang mau berpartisipasi dalam pembelajaran, terutama jika guru menggunakan strategi pembelajaran konvensional.

Kenyataan ini mungkin bisa diatasi dengan mengubah startegi pembelajaran menjadi lebih menarik dan menantang, misalnya dengan menggunakan model Cooperative Learning tipe Take and Give. Dilihat dari segi prosedur pelaksanaan pembelajaran, penerapan model cooperative laerning tipe take and give memberikan kemungkinan kepada peserta didik untuk terlibat secara aktif melalui partisipasinya dalam pembelajaran. Dengan demikian kualitas pembelajaran lebih baik dan bermakna bagi peserta didik. Namun hal ini tidak menjadi jaminan, karena kualitas suasana pembelajaran dipengaruhi oleh banyak faktor, baik faktor internal maupun faktor eksternal dari pribadi peserta didik dan pendidik.

Untuk itu penulis menganggap perlu melakukan penelitian mengenai penerapan model cooperative learning tipe take and give dalam kaitannya dengan partisipasi peserta didik dalam proses pembelajaran materi Otonomi Daerah, sehingga dapat diketahui bisa atau tidaknya meningkatkan partisipasi peserta didik dalam pembelajaran.

Dari uraian di atas, permasalahan dalam penelitian ini difokuskan pada penerapan model cooperative learning tipe take and give dan partisipasi peserta didik dalam proses pembelajaran. Dengan demikian dapat dirumuskan masalah penelitian sebagai berikut: Apakah melalui penerapan model pembelajaran Cooperative Learning tipe Take and Give dapat meningkatkan partisipasi peserta didik dalam pembelajaran materi Otonomi Daerah di kelas IX E SMP Negeri 9 Tasikmalaya tahun pelajaran 2017-2018? Secara umum penelitian ini bertujuan untuk meningkatkan partisipasi peserta didik dalam proses pembelajaran. 


\section{KAJIAN PUSTAKA}

\section{Pembelajaran Cooperative Learning Tipe Take and Give}

Cooperative learning atau pembelajaran kooperatif adalah strategi pembelajaran yang dikembangkan dengan prinsip sebagai berikut :

a. Dikembangkan dengan tujuan kelompok, yang menuntut kesamaan harapan kesamaan strategi dan kebersamaan dalam pencapaian target penguasaan kompetensi untuk setidaknya batas penguasaan dalam kerangka mastery learning.

b. Akuntabilitas individual, yakni tiap-tiap pesrta dalam kelompok haarus memiliki tanggung jawab untuk menguasai semua bahan ajar yang dipelajari dan siap untuk diuji dengan penguasaan minimal $80 \%$.

c. Masing-masing siswa mempunyai kesmpatan yang sama untuk mencapai sukses.

Pembelajaran kooperatif adalah strategi belajar mengajar yang menekankan pada sikap atau perilaku bersama dalam bekerja atau menyatu di antara sesama dalam struktur kerjasama yang teratur dalam kelompok (Slamet Mulyana, 2004: 70)

Model cooperative learning dalam penerapannya memiliki beberapa unsur seperti dikemukakan Roger dan David Johnson (dalam Lie, 2003: 31) yaitu:

a. Saling Ketergantungan Positif

Keberhasilan kelompopk sangat bergantung pada usaha setiap anggota kelompok.

b. Tanggung Jawab Perseorangan

Jika tugas dan pola penilaian dibuat menurut prosedur pembelajaran kooperatif, setiap siswa akan merasa bertanggung jawab untuk melakukan yang terbaik.

c. Tatap Muka

Setiap kelompok harus diberi kesempatan untuk bertemu muka dan berdiskusi. Kegiatan interaksi ini akan memberikan para pembelajar untuk membentuk sinergi yang menguntungkan semua anggota.

d. Komunikasi Antaranggota

Keberhasilan suatu kelompok bergantung pada kesediaan para anggota untuk saling mendengarkan dan mengutarakan pendapat mereka.

e. Evaluasi Proses Kelompok

Pengajar perlu menjadwalkan waktu khusus bagi kelompok untuk mengevaluasi proses kerja kelompok dan hasil kerja sama mereka agar selanjutnya dapat bekerja sama dengan lebih efektif.

Dari uraian di atas dapat disimpulkan bahwa pembelajaran kooperatif lebih menekankan pada sikap dan perilaku siswa dalam melakukan kerja sama. Dengan kerja sama, diharapkan pada diri peserta didik tumbuh rasa percaya diri, sehingga ia termotivasi untuk berperan serta dalam proses pembelajaran di antaranya kemauan mengemukakan pendapat. Lebih rinci Yan Sofyan (2003:3) mengemukakan pendapat bahwa: "Model cooperatif learning bermanfaat untuk : a) Mengurangi beban guru di kelas, b) menghilangkan kebosanan, baik guru maupun siswa, c) menghilangkan verbalisme, d) mengaktifkan siswa dalam proses belajarnya, e) meningkatkan kemandirian siswa dalam suasana gotong royong, dan f) memperoleh pengalaman belajar."

Model pembelajara kooperatif tipe take and give dapat digunakan dalam semua mata pelajaran dan untuk semua tingkat usia peserta didik. Dengan take and give peserta didik belajar mengenal dan memahami konsep atau topik dalam suasana yang menyenangkan.

Adapun langkah-langkah kegiatan penggunaan model pembelajaran kooperatif tipe take and give ini adalah sebagai berikut :

1. Siapkan kelas sebagaimana mestinya

2. Jelaskan materi sesuai kompetensi yang ingin dicapai 
3. Untuk memantapkan penguasaan peserta tiap peserta didik diberi masing-masing satu kartu untuk dipelajari (dihapal) lebih kurang 5 menit

4. Semua peserta didik disuruh berdiri dan mencari pasangan untuk saling memberi informasi. Tiap peserta didik harus mencatat nama pasangannya pada kartu contoh.

5. Demikian seterusnya sampai tiap peserta dapat saling memberi dan menerima materi masing-masing (take and give).

6. Untuk mengevaluasi keberhasilan berikan peserta didik pertanyaan yang tak sesuai dengan kartunya (kartu orang lain).

7. Strategi ini dapat dimodifikasi sesuai keadaan

8. Kesimpulan

\section{METODOLOGI PENELITIAN}

Penelitian ini akan dilaksanakan dengan menggunakan metode Penelitian Tindakan Kelas (classroom action research) yang berusaha mengkaji secara kolaboratif suatu alternatif proses pembelajaran sebagai penelitian yang bersifat reflektif dengan melakukan tindakan-tindakan tertentu agar dapat memperbaiki praktek pembelajaran di kelas. Penelitian Tindakan Kelas ini menggunakan modael yang mengacu kepada model Penelitian Tindakan Kelas yang dikemukakan oleh Kemmis dan Taggart (Hopkins, 2014 : 61).

Populasi pada penelitian ini adalah siswa kelas IX E SMP Negri 9 Tasikmalaya tahun pelajaran 2017/2018 dengan jumlah siswa 39 terdiri dari 22 siswa laki-laki dan 17 siswa perempuan. Beberapa pertimbangan peneliti dalam menetapkan subjek penelitian, antara lain:

1. Sebagian besar peserta didik kurang aktif dalam pembelajaran, khususnya dalam mata pelajaran PKn.

2. Situasi belajar di jam pelajaran akhir membuat peserta didik kelelahan dan terganggu konsentrasi belajarnya, terlebih-lebih banyak diantara peserta didik dari kelas lain sudah lebih dahulu pulang.

3. Perlunya perubahan strategi pembelajara baik menyangkut aktivitas guru maupun aktivitas peserta didik

Penelitian ini dilakukan secara kolaborative, yaitu adanya kolaborasi dari seorang guru pengajar dengan dua orang observer pada mata pelajaran yang sama dari sekolah lain. Keberadaan observer dipandang penting, disamping menunjukkan hasil pengamatannya juga memberikan masukan bagi perbaikan proses pembelajaran khusus dalam tahapan penelitian maupun untuk proses pembelajaran selanjutnya.

Penelitian tindakan kelas ini akan dilakukan dalam dua siklus, dan setiap siklus terdiri dari kegiatan perencanaan, tindakan atau pelaksanaa, pengamatan atau observasi dan refleksi.

\section{a. Perencanaan}

Pada tahap perencanaan, peneliti melakukan: identifikasi masalah, menentukan alternatif pemecahan masalah, penyusunan rencapa pelaksanaan pembelajaran, mempersiapkan media pembelajaran, menyiapkan alat evaluasi, membuat instrumen observasi dan mengundang dua orang pengajar mata pelajaran PPKn dari sekolah lain sebagai observer.

\section{b. Tindakan}

Kegiatan yang dilaksanakan dalam tahap ini adalah melaksanakan kegiatan pembelajaran sesuai perencanaan. Pada tahap ini peneliti melaksanakan tindakan sesuai dengan skenario pembelajaran yang telah dibuat, yakni dengan menggunakan model pembelajaran koperatif tipe Take and Give dalam dua siklus: siklus pertama dilakukan pada 19 Oktober 2017 sedangkan siklus kedua dilaksanakan pada 2 Novemver 2017. 


\section{c. Observasi}

Kegiatan yang dilakukan pada tahap pengamatan (observation) adalah observer mengamati aktivitas peserta didik dan aktivitas guru selama peroses pembelajaran pada setiap siklus dengan menggunakan lembar observasi dan catatan lapangan. Langkah ini diperlukan untuk menemukan kelebihan dan kekurangan yang terjadi pada pelaksaan pembelajaran sebagai bahan masukan kepada guru pengajar demi peningkatan kualitas pembelajaran pada siklus berikutnya.

\section{d. Refleksi}

Tahap refleksi (reflection) merupakan tahap akhir dari siklus penelitian tindakan kelas. Pada tahap refleksi peneliti bersama observer (guru) mendiskusikan hasil pengamatan dari tindakan yang telah dilaksanakan serta permasalahan yang timbul di kelas penelitian. Hasil dari tahap ini dijadikan sebagai dasar pembuatan rencana tindakan pada siklus berikutnya.

\section{HASIL PENELITIAN DAN PEMBAHASAN}

Penelitian dilaksanakan pada bulan Oktober dan Nopember 2017 dengan dua siklus masing-masing satu kali pertemuan.

\section{Siklus I}

Siklus pertama dilakukan pada 19 Oktober 2017. Kegiatan pembelajaran diawali dengan memberi kesempatan kepada peserta didik untuk mengkaji buku sumber mengenai Makna Otonomi Daerah yang dilanjutkan dengan penjelasan singkat dari guru. Berikutnya setiap siswa menerima satu kartu konsep dan satu kartu informasi, kartu konsep berisi konsep materi yang harus dikuasai dan dijelaskan kepada peserta didik lain, sedangkan kartu informasi berupa blanko nama teman dan judul konsep yang harus diisi pada saat memberikan dan menerima informasi. Di sini materi diorganisir menjadi enam konsep. Setelah menguasai konsep yang diterima peserta didik mencari teman yang memiliki konsep yang berbeda untuk saling menjelaskan, kemudian nama dan judul kosep ditulis di kartu informasi. Demikian seterusnya sampai semua konsep yang menjadi bahan kajian bisa diterima dan dipahami. Langkah berikutnya guru mempersilah peserta didik untuk mempresentasikan konsep materi yang menjadi tugasnya dan materi yang diterima dari teman-temannya selama proses pelaksanaan pembelajaran take and give secara bergantian.

Pada siklus pertama ini, dilakukan pengamatan oleh dua observer untuk mengamati aktivitas peserta didik dan aktivitas guru selama proses pembelajaran. Aktivitas peserta didik meliputi sebelas butir pengamatan, sedangkan aktivitas guru 19 butir pengamatan, setiap butir dinilai kualitasnya: baik dengan nilai tiga, jika angka partisipasi peserta didik mulai $70 \%$ sampai $100 \%$, cukup dengan nilai dua, jika angka partisipasi peserta didik mulai 50\% sampai $69 \%$ dan jelek dengan nilai satu, jika angka partisipasi peserta didik di bawah 50\%. Data hasil pengamatan dicari reratanya kemudian membandingkannya dengan skor maksimal untuk aktivitas peserta didik sebesar 33 sedangkan aktivitas guru 57.

Berdasarkan hasil pengamatan, diperoleh data skor rerata kedua observer adalah 26,5. Dengan demikian angka partisipasi peserta didik dalam proses pembelajaran di siklus pertama ini sebesar $80,30 \%$ dan dikategorikan baik. Sedangkan skor rerata aktivitas guru sebesar 45,5 yang berarti aktivitas guru sebesar 79,83\% dikategorikan baik.

Setelah siklus pertama selesai, dilakukan refleksi berkaitan dengan kelebihan dan kekurangan proses pembelajaran. Bahwa meskipun berdasarkan hasil pengolahan data disimpulkan aktivitas peserta didik dan guru sudah baik, namun masih mungkin untuk ditingkatkan, yaitu dengan memperbaiki beberapa kekurangan diantaranya mengurangi dominasi guru pada fase penjelasan guru, peningkatan kemampuan pengelolaan kelas, pelibatan peserta didik dalam tahap konfirmasi dan memperbaiki instrument pengamatan. Demikian hasil kesepakatan guru dengan observer pada saat refpleksi. 


\section{Siklus II}

Berpedoman pada perencanaan yang dibuat berdasarkan kesepakatan saat refleksi siklus pertama, maka dilaksanakan tindakan siklus kedua pada tanggal 2 November 2017. Pembelajaran diawali dengan kegiatan studi pustaka dilanjutkan dengan penjelasan singkat dari guru, kemudian siswa menerima kartu konsep dan kartu informasi. Materi pembelajaran diorganisir menjadi delapan butir konsep. Setiap siswa mempelajari satu konsep yang diterima untuk dijelaskan kepada peserta didik lain. Selanjutnya peserta didik mencari teman dengan konsep yang berbeda sebanyak tujuh orang, dengan harapan kedelapan konsep yang dipelajari mampu dikuasai peserta didik.

Langkah berikutnya guru mempersilahkan peserta didik tampil mempresentasikan penguasaan materinya dengan didampingi teman-teman yang ditemuinya untuk memberikan konfirmasi. Demikian dilakukan secara bergantian.

Pada siklus kedua ini, dilakukan pengamatan oleh seorang observer untuk mengamati aktivitas peserta didik dan aktivitas guru selama proses pembelajaran. Perubahan jumlah observer terjadi karena salah seorang observer berhalangan hadir. Berdasarkan hasil pengamatan di siklus kedua, diperoleh data skor aktivitas peserta didik sebesar 32 berbanding skor maksimum 33. Dengan demikian angka partisipasi peserta didik dalam proses pembelajaran di siklus kedua ini sebesar 96,97\% dan dikategorikan baik. Sedangkan skor aktivitas guru sebesar 52 berbanding skor maksimal 57 yang berarti aktivitas guru sebesar 91,23\% dikategorikan baik.

Setelah siklus kedua selesai, dilakukan refleksi berkaitan dengan kelebihan dan kekurangan proses pembelajaran. Di siklus kedua ini telah terjadi perbaikan dari sisi peserta didik menjadi lebih aktif sedangkan aktivitas guru mergeser ke perannya sebagai fasilitator di kelas.

Berdasarkan data-data yang diperoleh dari pelaksanaan tindakan pada siklus pertama dan kedua terbukti bahwa partisipasi peserta didik dalam proses pembelajaran meningkat seiring perbaikan pada perencanaan dan pelaksanaan pembelajaran. Peningkatan partisipasi peserta didik dapat dijelaskan dalam grafik berikut ini:

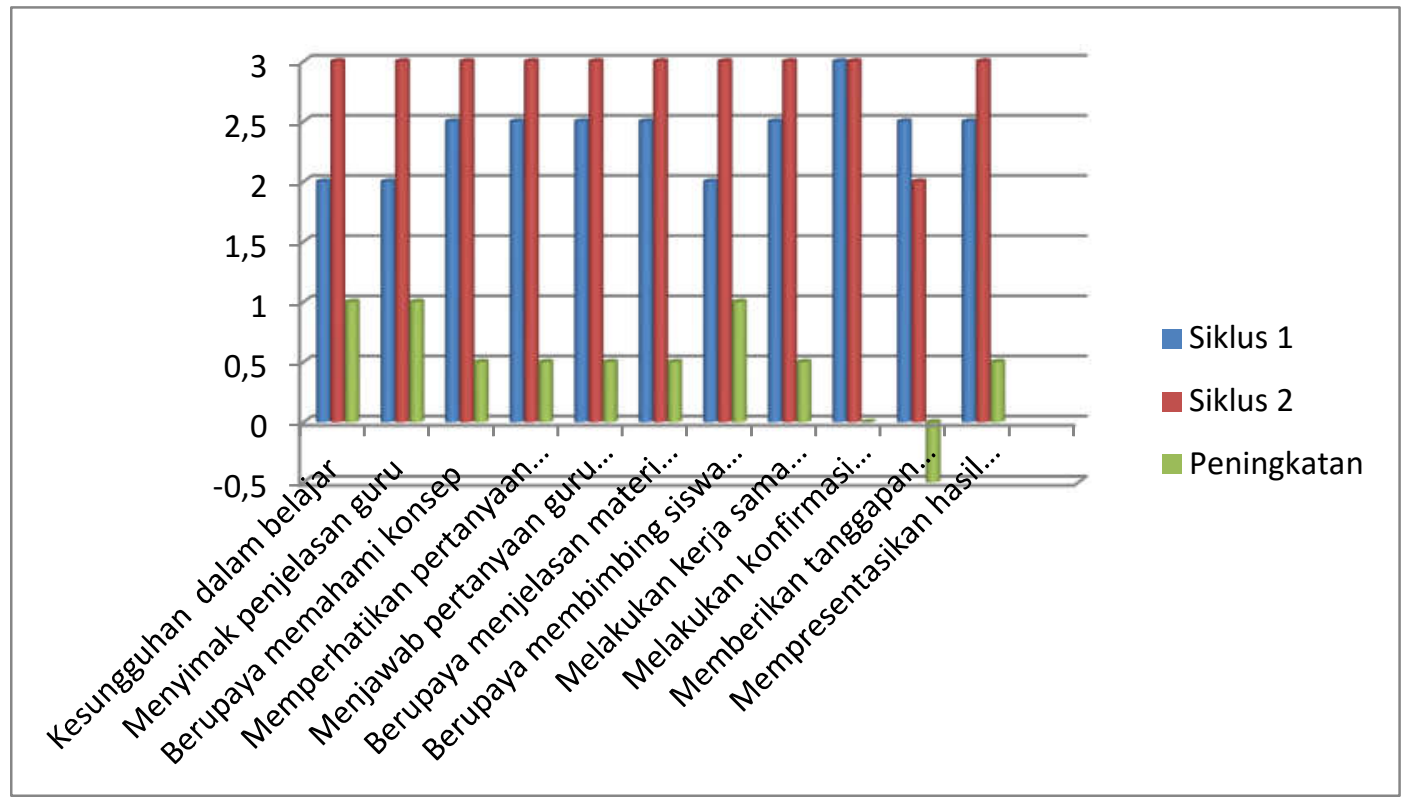

Grafik 1 : Rekapitulasi Data Observasi Aktivitas Siswa pada Siklus Kesatu dan Kedua

Dari grafik 1, dapat ditemukan informasi bahwa dengan membandingkan nilai aktivitas peserta didik siklus kesatu dengan siklus kedua telah terjadi peningkatan kualitas 
aktivitas peserta didik dari keseluruhan indikator sebesar lima koma lima $(5,5)$, ini berarti ada terjadi peningkatan $\frac{5,5}{33} \times 100 \%$, atau 16,67\%. Angka ini dapat ditemukan pula dengan cara mengurangi nilai aktivitas peserta didik siklus dua dengan nilai aktivitas peserta didik dari siklus satu; 96,97\% - 80,30 = 16,67\%. Peningkatan sebesar ini ditunjang oleh peningkatan tiap indikator yang tersebar di hampir seluruh indikator.

Pencapaian nilai aktivitas peserta didik pada siklus kedua sebesar 96,97\%, dapat ditafsirkan bahwa, partisipasi peserta didik pada siklus ini telah mendekati nilai sempurna, selama kita melihatnya dari penentuan kategori penilaian: baik untuk aktivitas peserta didik mulai $70 \%$ sampai dengan $100 \%$, cukup untuk aktivitas peserta didik mulai $51 \%$ sampai dngan $69 \%$, dan jelek untuk aktivitas peserta didik mulai $0 \%$ samapai dengan $50 \%$.

\section{KESIMPULAN DAN SARAN}

Berdasarkan data pada bagian deskripsi hasil penelitian khususnya data hasil observasi dan refleksi serta bagian pembahasan dalam penelitian tindakan kelas ini, dapat disimpulkan bahwa penerapan model cooperative learning tipe take and give dapat meningkatkan partisipasi peserta didik dalam pembelajaran PPKn pada materi Otonomi Daerah di kelas IX E SMP Negeri 9 Tasikmalaya tahun pelajaran 2017/2018.

Penerapan model cooperative learning tipe take and give telah terbukti dapat meningkatkan partisipasi peserta didik dalam pembelajaran PPKn. Oleh karena itu penulis mengajak khususnya kepada sesama guru untuk lebih kreatif dan inovatif dalam mengembangkan, memodifikasi dan mengadaftasi modelmodel pembelajaran sehingga efektivitas dan efisian proses pembelajaran lebih baik.

\section{DAFTAR PUSTAKA}

[1] Hopkins, David. 2014. A Teachers Guide to Clasroom Research, fifth adetion. New York: Open University Press

[2] Lie, Anita. 2003. Cooperative Learning. Jakarta. Gramedia

[3] Mulyana, Slamet.2004.Model-model Pembelajaran. Bandung. Depdiknas LPMP

[4] Rosyada, Dede. 2004. Paradigma Pendidikan Demokratis. Jakarta. Prenada Media

[5] Sumartini, Ai Tin. 2006. Modul Pembelajaran Pendidikan Kewarganegaraan Kelas IX Semester 2. Tasikmalaya: MGMP Kewarganegaraan SMP/MTs

[5] Supyan, Yan. 2007. Model Pembelajaran Cooperative Learning. Tasikmalaya: MGMP Sejarah(tidak diterbitkan) 